\title{
The Sleeping Giant: The Awakening of Religious Identity
}

\author{
Sugit S. Arjon \\ Graduate School of International Relations \\ Ritsumeikan University \\ Kyoto, Japan \\ gr0298vk@ed.ritsumei.ac.jp
}

\begin{abstract}
The fall of Suharto's New Order should be considered as the starting point of the sublime journey of the political identity which often implicates religions and ethnicity under the democracy practices. Religious identity is a sleeping giant, which has awakened in the past and which will awake in the future again. Plenty of fundamentalist groups are formed and hide within the concept of freedom and democracy. Those organizations are using democracy to destroy its fundamental principles.
\end{abstract}

Indonesia regularly has experienced large-scale violence. Namely, Jakarta, Sambas, Sampit, Aceh, Poso, Moluccas, West Papua, these were areas which strongly associated with violence and it often implicated religion, ethnicity, and race as the roots of violence. Some of the past violence occurred during a democratic transition between 1998-2004, it started to decline after the local autonomy being implemented, and it is currently back on the rise.

This article examines the role of political identity in democratic practices, and it also discusses the possibility of the awakening the religious and ethnicity sentiment under Joko Widodo (Jokowi) administration. How the fundamentalist portrayed and framed themselves under democracy practices and why it is back on the rise. The nation is currently split into two sides: nationalist ideology vs. religious ideology, the construction image of us versus them provoke the disruptive of social and political processes, it also challenges the peace and harmony in the nation.

Keywords - conflicts; identity; peacebuilding; violence; political identity; nationalist; religious; riots

\section{INTRODUCTION}

Indonesia has the biggest Muslim population on earth. However, Indonesia is not an Islamic nation. Many experts on democracy argue that Indonesia can play an important role as a model of Muslim democracy. Why does Indonesia deserve to be labeled as a magnificent example of Muslim democracy? Is it because of consolidated and stable democratic government? Is it because of the excellent economic growth?

I argue Indonesia is not a place to be a model that Muslim and democracy can work. Why? Historically speaking, Indonesia has the habit of using religious identity for its political interests. This practice has resulted in several ethnic conflicts and religious riots. Indonesia is a country which regularly has experienced large-scale violence in the past two decades, namely, Jakarta, Sambas, Poso, Moluccas, and West Papua. Due to this frequent political violence, thus, Indonesia will never be able to maintain its social and political stability. Even though in some cases, the political struggle due to a religious sentiment which aims for the political interests will be silent for a few years, it is like a sleeping giant, once it's awake, it will destroy everything that has been built. The riots because of religious or ethnic sentiments is not a new thing in Indonesia. Historical evidence showed us that long before its independence, Indonesians have been fighting over religious or ethnic sentiment among them. Moreover, after its independence in 1945, Indonesians still fought over religious and ethnic sentiment among them. The fact shows that since its independence, numerous Indonesians are losing lives due to conflicts. Despite the economic and national political reforms, domestic security issues remain as an important issue because it implicates religious violence, communal conflicts, and ethnic violence because it is continuing to pose a threat to the people. The causes of violent conflict are also driven by the rise towards intolerance, which mainly involved ethnicity, race, gender, and religions. Some scholars argue that those intolerance acts are commonly triggered by poverty, political, social, and economic inequalities between groups, which lead to conflict. Moreover, Indonesia's society consists of numerous ethnic groups, races, and religion. Since most people in Indonesia live in the high number of diversities, it makes them prone to conflict. Furthermore, one of the most common battles happened in Indonesia due to religious identities, and it can transform political disputes in ways that ideologies and organizations cannot. As an example, conflict in Ambon in 1999-2002, it permits violent expression and uses religion as a basis of group identity. Moreover, religious and ethnic violence tend to spread quickly than any other conflict and violence. 
Many scholars argue that the rise tension during Jakarta gubernatorial election in 2017 tend to spread the hate among Indonesians and the campaign itself boost the religious and ethnicity sentiments. Is this the sign of waking giant that has been sleeping since its last appearance in 1998 ? Will it affect the post-conflict areas which have experienced the violence due to religious and ethnicity sentiments?

This article uses qualitative method followed by a semi-structured interview. The interviews with scholars were using in-depth interviews. Some part of this article was a literature review of the existing study on this issue.

\section{SOCIAL AND POLITICAL CONTEXT IN INDONESIA}

Indonesia has faced two political transitions since 1998, the first political development was in 1998 from autocracy to democracy, and second, in 2004, a drastic change from political and administrative centralize government to the decentralization. These political developments were arguably increasing the vulnerability to violence which makes Indonesia prone to conflict. The political transition creates chaos because the vast 'cake' which was customarily formulated and arrange from Jakarta and distributed to the region, switched, which makes the local elites fight for their share within the political power and wealth. The central question was, once Indonesia successfully muffled the violent conflicts, does it mean Indonesia is in the safe zone from the future strife to erupt? I highly doubt it. The conflict will always happen in Indonesia; it is just a matter of time when it will erupt. Does it mean Indonesia cannot avoid it to happen? They could, but it will only delay the conflict or move the conflict somewhere else. In Indonesia, somehow, religion and ethnicity have become the political force to influence and mobilize the masses. "Religious violence does not just happen, and it is both politically organized and efficacious".

\section{A. New challenges, old problems}

The role that religion and ethnicity play in daily life and even more in political participation is frightening. Religion and ethnicity could split into two, both at the national level and at the regional level. The recent case in Jakarta gubernatorial 2017 election shows that religious and ethnic identity plays a significant role.

Religious and ethnic identity sentiment can never be justified, especially in a diverse nation such as Indonesia. Indonesia's society consists of numerous ethnic groups, races, languages, and religions. Hence, religious and ethnic identity sentiments should never be allowed. The results of these sentiments create polarization and segregation within the society which could be the beginning of the disunity of a nation.

The hypothesis of the awakening of religious identity has to be proven in an election in the context of national level. Moreover, the sentiment on political identity has been on the rise several times, and it has its symptoms. Post-1998, the noise and the spread of religious sentiment and political identity is because of the echoes which made by the advancement of technology.

Confirmation, verification, and validation become limited and exceptional. The verification that was used to be the basis of a news story is often missed and revised edition become popular among the mainstream media. For the readers, the revised version is not as popular as the misleading news in the first place. Public become lost and does not know who to trust.

Hence, the author argues that mainstream media, especially the current ones and followed by the advancement of technologies, news are using social media to spread its stories and it plays a significant role in the polarization and split the society.

Furthermore, the author argues that religious sentiments are often echoed to attack and to frame an individual, political ideology, and groups. Mainstream media through the function of social media is normally non-objective for mounting those groups mentioned earlier.

Moreover, conflicts and riots based on religions and ethnicity tend to erupt and spread quickly than any other forms of conflict and violence in Indonesia. It is debatable because many Indonesians often considered ethnicity and religion as a primary part of their main identity. Although theoretically speaking, religious identities cannot be separated from bigger identity consciousness structure such as ethnicity, language, race, caste, tribe, kinship, and region.

Brubaker (2015) explains that there is no intrinsic connection between religion and political violence. However, religion does provide a potential mass of moral, ideological, and organizational resources the personal level that can work in specific contexts, inform, legitimate, or sustain the most admirable forms of moral and political engagement. Moreover, religious factor was introduced into the conflict through the fears and played on social insecurities among other factors. In contrast, those who took part in the conflict violence were not interested in political issues, democratization, nor 
contestation of power which influence the conflict, for them it is all about religions, political or economic issues were just camouflage for the destruction of a religious community.

Moreover, when we discuss the spread of political violence, which causes by the religion and ethnicity sentiment, we cannot leave behind the symbol, image, leader, nor the place of worship for its followers. Mosques, churches, religious leaders such as Imams and priests were fundamental on spreading conflict in Ambon between 1999-2002. At some point during the conflict, Imams in North Moluccas taught their followers how to do the archery and explained the rules of war according to Islam in Sharia law.

\section{B. The importance of religious and ethnic leaders}

Both Indonesians on the side of religious or nationalist, they tend to put their trust on the particular figure instead of on ideology or beliefs. Hence, during the conflict and political violence, the leaders such as Imams or priests from the religious leaders, or tribal chiefs or local kings from the ethnic group leaders play rather a crucial role on escalating the conflict or preventing the conflict.

It is unfortunate that the Indonesian government tends to marginalize the role of two crucial aspects in Indonesia which are religious and ethnic. The facts show that mosques and Imams played an essential role in conflicts. Moreover, the Indonesian government frequently exclude the religious and traditional leaders on the discussion of conflict. The Indonesian government rather abandons their role until the end. Thus, it is very understandable when Ja'far Umar Thalib was able to gather plenty of people in short time to join him to perform jihad in the Moluccas. Even during the conflict in the Moluccas, the majority of mosques and Imams were giving their blessings to people who fought the holy war. They also gave their blessing to the jihadists and their weapons such machete, so that they will immune from the attack of the enemy of Islam.

Take Jakarta gubernatorial 2017 election as an example. It was all started a year before the election, and the campaign exploited the use of mosques and its Imams on the political campaign. It shows that the government lacks attention to them. Focus does not mean that the government has to control or regulate the content of khotbah, but, hoaxes and misleading information were mere because the government lacks to provide additional information for the public to equalize the misleading information. The government has to provide the correct information, instead of pro- government propaganda. Propaganda progovernment (nationalist) program will only foster the escalation of conflict and the resistance towards the government will grow in advance. This lack of trust in the government can lead to political violence and or state-sponsored violence.

The next argument is that the role of social media is enormous on the escalation of hoaxes and propaganda. Indonesia second least literate of 61 countries and this make it easier to spread the propaganda to the Indonesian people.

\section{AN OPPORTUNITY ON THE RISE}

There are plenty of opportunity in President Jokowi administration, as long as he can utilize the chances, he might deliver the political stability during his administration.

\section{A. Robust connection with Nahdlatul Ulama (NU)}

The non-state actors played an important role in spreading and rose the tension during the conflict. Take conflict in Ambon between 1999-2002 as an example. The religious institutions such as mosques and churches were actively involved in the bloody conflict. The religious leaders in both religions were actively engaged and encourage the preachers to participate in the holy war. Moreover, the role of religious, racial, and ethnic institutions perfectly worked during the conflict in Ambon in 2002. The Muslim fighters decided to return to their home and live peaceful lives after the respected leading clerics persuaded them in religious terms with persuasive overtures, diplomacy, and their willingness to shutting down their organizations and things which may lead them back into conflict violence.

Moreover, President Jokowi has a robust connection with the most prominent traditionalist Islam movement in Indonesia, Nahdlatul Ulama (NU) and Muhammadiyah. He has to show it the public that these organizations are the modernist, able to calm the hardliners through the peaceful content of dakwah. The only way to fight the fundamentalist is not to put them in prison, but the government needs to engage more with the modernists and ask them to approach every Muslims and teach peaceful Islam. The Muslims will see which teachings suit the Indonesia's condition with its large number of diversity.

\section{CONCLUSION}

Indonesians tend to consider ethnicity and religion as a primary part of their main identity. That would be the reason why Indonesia has regularly experienced large-scale violence for the past two 
decades. Indonesia will never be a place to be a model that Muslim and democracy can work. Political stability is required in a democracy, and it will not be achieved when the political violence due to religion and or ethnicity still occurs on a daily basis. The fact that Indonesia is a diverse nation will make it even hard to achieve stability and avoid conflicts. However, it can be delayed once the government tries to engage more with the spiritual and ethnicity leaders across Indonesia. The religious and ethnicity leaders play the crucial role in escalating the conflict or preventing the conflict. Ja'far Umar Thalib was able to gather many people to perform jihad in a short time. Since the Indonesia ranked as the second least literate of 61 nations in 2016, thus, the government needs to supply plenty of information to the public to improve the literacy level. The government also needs to collaborate with the most significant Muslim organizations in Indonesia such as NU and Muhammadiyah.

\section{ACKNOWLEDGEMENT}

A Kokusaiteki research fund at the Ritsumeikan University supported this research

\section{BIBLIOGRAPHY}

Ackermann, A. (2003). The Idea and Practice of Conflict Prevention. Journal of Peace Research, 40(3), 339347.

Arjon, S. S. (2015). Political Influence of Local and International NGOs in Domestic Policymaking Processess: Kidnapping Prevention in Colombia. Master's Thesis at University of Amsterdam, 1-70.

Bertrand, J. (2004). Nationalism and Ethnic Conflict in Indonesia. Cambridge: Cambridge University Press.

Brubaker, R. (2015). Religious Dimensions of Political Conflict and Violence. Sociological Theory, 33(1), 1-19.

Craig, G. A., \& George, A. L. (1995). Force and Statecraft: Diplomatic Problems of Our Time. New York: Oxford University Press.

Drexler, E. (2006). Provoking violence, authenticating separatism: Aceh's humanitarian pause. In C. A. Coppel, Violent conflicts in Indonesia: analysis, representation, resolution (pp. 163-173). New York: Routledge.

Duncan, C. R. (2013). Violence and Vengeance: Religious Conflict and Its Aftermath in Eastern Indonesia. New York: Cornell University Press.

Evans, G. (2008). The Responsibility to Protect: Ending Mass Atrocity Crimes Once and For All. Washington D.C: The Brookings Institution Press.

Friedland, R. (2015). The Constitution of Religious Political Violence: Institution, Culture, and Power. The Oxford Handbook of Cultural Sociology, 1-49.

Galtung, J. (1969). Violence, Peace, and Peace Research. Journal of Peace Research, 6(3), 167-191.
Gunawan S., A. (2016, 03 12). Indonesia second least literate of 61 nations. Retrieved from The Jakarta Post:

http://www.thejakartapost.com/news/2016/03/12/in donesia-second-least-literate-61-nations.html

Hauss, C. (2001). International Conflict Resolution: International relations for the 21 st century. New York: Continuum.

Jentleson, B. W. (1998). Preventive diplomacy and ethnic conflict: Possible, difficult, necessary. In D. A. Lake, \& D. Rothchild, The international spread of ethnic conflict: fear, diffusion, and escalation (pp. 293-316). Princeton: Princeton University Press.

Min, S. S. (2006). 'Eventing' the May 1998 affair: problematic representations of violence in contemporary Indonesia. In C. A. Coppel, Violent conflicts in Indonesia: analysis, representation, resolution (pp. 39-57). New York: Routledge.

Nordholt, H. S. (2002). A genealogy of violence. In F. Colombijn, \& J. T. Lindblad, Roots of violence in Indonesia: Contemporary violence in historical perspective (pp. 33-62). Leiden: KITLV Press.

Panggabean, S. R. (2006). Educating to handle conflict and avoid violence. In C. A. Coppel, Violent conflicts in Indonesia: analysis, representation, resolution (pp. 217-228). New York: Routledge.

Scherrer, C. P. (2002). Structural Prevention of Ethnic Genocide. New York: Palgrave MacMillan. 